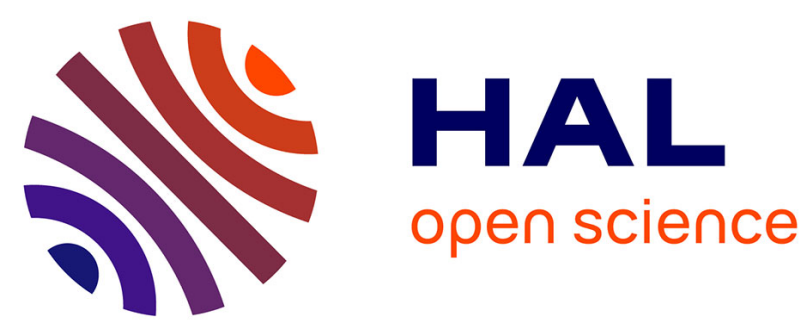

\title{
Dietary acrylamide exposure among Finnish adults and children: The potential effect of reduction measures
}

Tero Hirvonen, Marika Jestoi, Heli Tapanainen, Liisa Valsta, Suvi M

Virtanen, Harri Sinkko, Carina Kronberg-Kippilä, Jukka Kontto, Jarmo

Virtamo, Olli Simell, et al.

\section{To cite this version:}

Tero Hirvonen, Marika Jestoi, Heli Tapanainen, Liisa Valsta, Suvi M Virtanen, et al.. Dietary acrylamide exposure among Finnish adults and children: The potential effect of reduction measures. Food Additives and Contaminants, 2011, pp.1. 10.1080/19440049.2011.593559 . hal-00719071

\section{HAL Id: hal-00719071 \\ https://hal.science/hal-00719071}

Submitted on 19 Jul 2012

HAL is a multi-disciplinary open access archive for the deposit and dissemination of scientific research documents, whether they are published or not. The documents may come from teaching and research institutions in France or abroad, or from public or private research centers.
L'archive ouverte pluridisciplinaire HAL, est destinée au dépôt et à la diffusion de documents scientifiques de niveau recherche, publiés ou non, émanant des établissements d'enseignement et de recherche français ou étrangers, des laboratoires publics ou privés. 


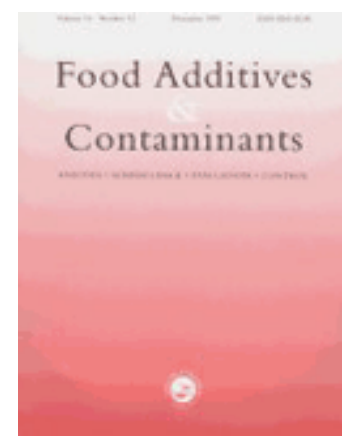

\section{Dietary acrylamide exposure among Finnish adults and children: The potential effect of reduction measures}

\begin{tabular}{|c|c|}
\hline Journal: & Food Additives and Contaminants \\
\hline Manuscript ID: & TFAC-2011-074.R1 \\
\hline Manuscript Type: & Original Research Paper \\
\hline $\begin{array}{r}\text { Date Submitted by the } \\
\text { Author: }\end{array}$ & 24-May-2011 \\
\hline Complete List of Authors: & $\begin{array}{l}\text { Hirvonen, Tero; Finnish Food Safety Authority Evira, Risk } \\
\text { Assessment Unit } \\
\text { Jestoi, Marika; Finnish Food Safety Authority, Research Department } \\
\text { Tapanainen, Heli; National Institute for Health and Welfare, } \\
\text { Department of Lifestyle and Participation } \\
\text { Valsta, Liisa; National Institute for Health and Welfare, Department } \\
\text { of Lifestyle and Participation } \\
\text { Virtanen, Suvi; National Institute for Health and Welfare, } \\
\text { Department of Lifestyle and Participation } \\
\text { Sinkko, Harri; National Institute for Health and Welfare, } \\
\text { Department of Lifestyle and Participation } \\
\text { Kronberg-Kippilä, Carina; National Institute for Health and Welfare, } \\
\text { Department of Lifestyle and Participation } \\
\text { Kontto, Jukka; National Institute for Health and Welfare, } \\
\text { Department of Chronic Disease Prevention } \\
\text { Virtamo, Jarmo; National Institute for Health and Welfare, } \\
\text { Department of Chronic Disease Prevention } \\
\text { Simell, Olli; University of Turku, Department of Pediatrics } \\
\text { Peltonen, Kimmo; Finnish Food Safety Authority, Research } \\
\text { Department }\end{array}$ \\
\hline Methods/Techniques: & Exposure assessment, Statistical analysis \\
\hline Additives/Contaminants: & Process contaminants - acrylamide \\
\hline Food Types: & Cereals, Beer, Coffee, Snack products \\
\hline Abstract: & $\begin{array}{l}\text { A deterministic exposure assessment using the Nusser method that } \\
\text { adjusts for within-subject variation and for nuisance effects among }\end{array}$ \\
\hline
\end{tabular}


Note: The following files were submitted by the author for peer review, but cannot be converted to PDF. You must view these files (e.g. movies) online.

Acrylamide_intake_adults_children_version_IV_TRK_rev.docx

Finnish children and adults was carried out. The food consumption data covered 2,038 adults (25-74 years old) and 1,514 children of one, three, and six years of age, with the data on foods' acrylamide content obtained from published Finnish studies. We found that acrylamide exposure was highest among the three-year-old children (median: $1.01 \mu \mathrm{g} / \mathrm{kg}$ bw / day, 97.5th percentile: $1.95 \mu \mathrm{g}$ / kg bw/ day) and lowest among 65-74-year-old women (median: $0.31 \mu \mathrm{g} / \mathrm{kg}$ bw/ day, 97.5 th percentile: $0.69 \mu \mathrm{g} / \mathrm{kg} \mathrm{bw} /$ day). Among adults, the most important source of acrylamide exposure was coffee, followed by casseroles rich in starch, then rye bread. Among children, the most important sources were casseroles rich in starch and, then, biscuits and, finally, chips and other fried potatoes. Replacing lightly roasted coffee with dark roasted, swapping sweet wheat buns for biscuits, and decreasing the acrylamide content of starch-based casseroles and rye bread by $50 \%$ would result in a $50 \%$ decrease in acrylamide exposure in adults. Among children, substituting boiled potatoes for chips and other friend potatoes and replacing biscuits with sweet wheat buns while lowering the acrylamide content of starch-based casseroles by $50 \%$ would lead to acrylamide exposure that is only half of the original exposure.

Conclusions: Dietary modifications could have a large impact in decreasing acrylamide exposure.

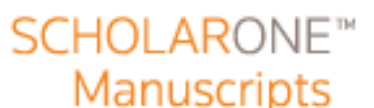


Table 1: Acrylamide content $(\mu \mathrm{g} / \mathrm{kg})$ of foods used in calculation of intake, with values for highest concentrations, most important sources, and substitutes to lower the intake (sweet wheat buns, coffee made from dark-roasted beans, and cooked potatoes)

\begin{tabular}{|c|c|c|c|c|c|c|}
\hline \multicolumn{7}{|c|}{ Finnish studies } \\
\hline Food & $n$ & Mean (min.-max.) & Food & $n$ & Mean (min.-ma & ax.) \\
\hline Crispbread $^{1}$ & 23 & $674(<68-1,480)$ & Muesli $^{1}$ & 10 & $100(<68-100)$ & \\
\hline Crisps $^{1}$ & 15 & $539(100-1,470)$ & Rye bread $^{2}$ & 3 & $51(<40-80)$ & \\
\hline Sweet biscuits ${ }^{1}$ & 15 & 443 & $\begin{array}{l}\text { Karelian } \\
\text { pastry }^{2}\end{array}$ & 1 & 43 & \\
\hline Popcorn $^{1}$ & 3 & 300 & Cracker $^{1}$ & 2 & $128(120-134$ & \\
\hline $\begin{array}{l}\text { Chips and } \\
\text { oven-baked } \\
\text { sliced potatoes }\end{array}$ & 17 & 286 & Wheat rusk $^{1}$ & 1 & 0 & \\
\hline Salted biscuits $^{1}$ & 2 & $179(134-224)$ & Beer $^{2}$ & 2 & 0 & \\
\hline $\begin{array}{l}\text { Potato-ham } \\
\text { casserole } \\
\text { (heated) }^{1}\end{array}$ & 5 & $151(0-223)$ & $\begin{array}{l}\text { Sweet wheat } \\
\text { bun }^{1}\end{array}$ & 2 & 0 & \\
\hline \multirow[t]{2}{*}{$\begin{array}{l}\text { Toast (heavily } \\
\text { toasted) }\end{array}$} & 5 & $111(<75-115)$ & $\begin{array}{l}\text { Coffee, light } \\
\text { roast }^{2}\end{array}$ & $\underline{4}$ & $15(11-20)$ & \\
\hline & & & $\begin{array}{l}\text { Coffee, dark } \\
\text { roasted }^{2}\end{array}$ & $\underline{2}$ & $5(<10)$ & \\
\hline \multicolumn{7}{|c|}{ Other studies } \\
\hline Food & Value used & Food & Value used & Food & Value used & \\
\hline Doughnut $^{4}$ & $<30-40$ & $\begin{array}{l}\text { White bread } \\
\text { (non-toasted) }^{3}\end{array}$ & 15 & Fish finger $^{2}$ & 15 & \\
\hline Fried potato $^{2}$ & 310 & Sausage $^{2}$ & 15 & Sponge cake $^{3}$ & 28 & \\
\hline Danish pastry $^{2}$ & $<30$ & $\begin{array}{l}\text { American } \\
\text { muffins }^{2}\end{array}$ & 50 & Corn flakes $^{3}$ & 121 & \\
\hline Pasta $^{2}$ & 15 & Pancake $^{2}$ & 15 & Beef burger ${ }^{3}$ & 15 & \\
\hline
\end{tabular}

${ }^{1}$ Eerola et al. ${ }^{2}$ Hirvonen et al. ${ }^{3}$ Svensson et al. ${ }^{4}$ Konings et al. 


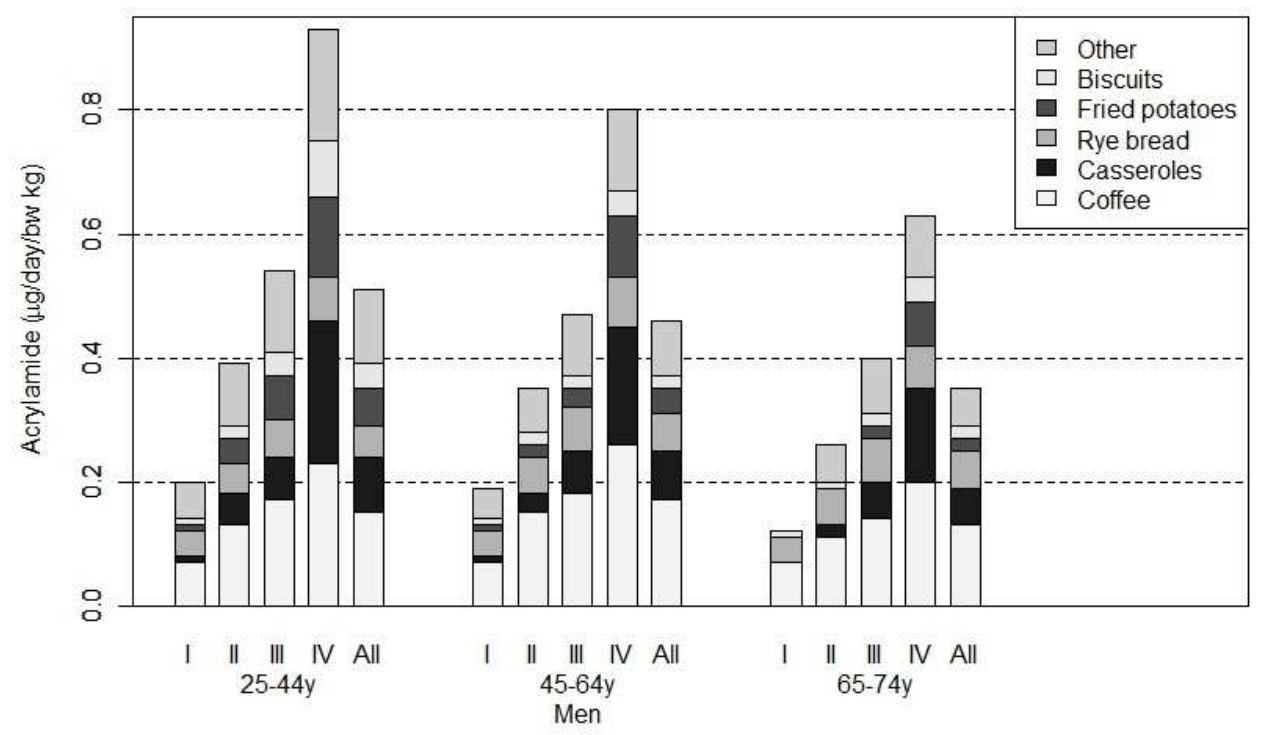

Dietary acrylamide exposure among men by major source, by age group, and by intake quartile. $293 \times 194 \mathrm{~mm}(72 \times 72$ DPI $)$ 


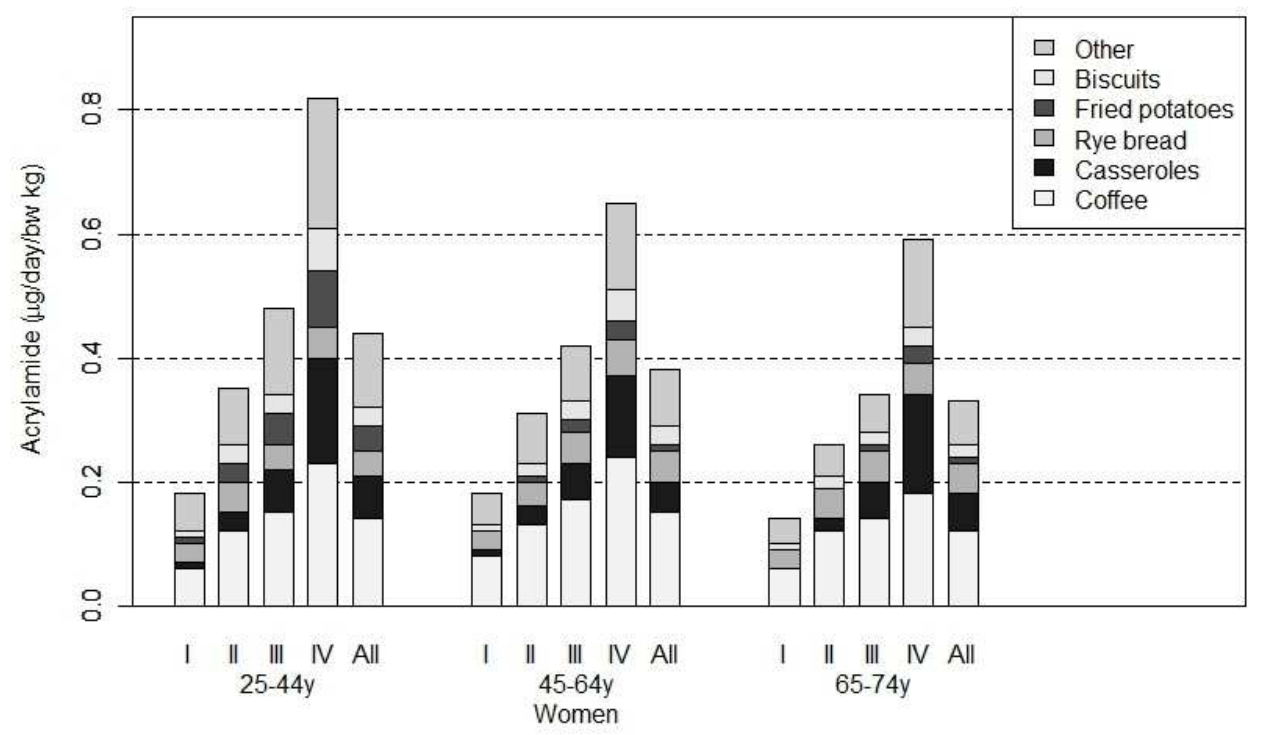

Dietary acrylamide exposure among women by major source, by age group, and by intake quartile. $293 \times 194 \mathrm{~mm}(72 \times 72$ DPI $)$ 


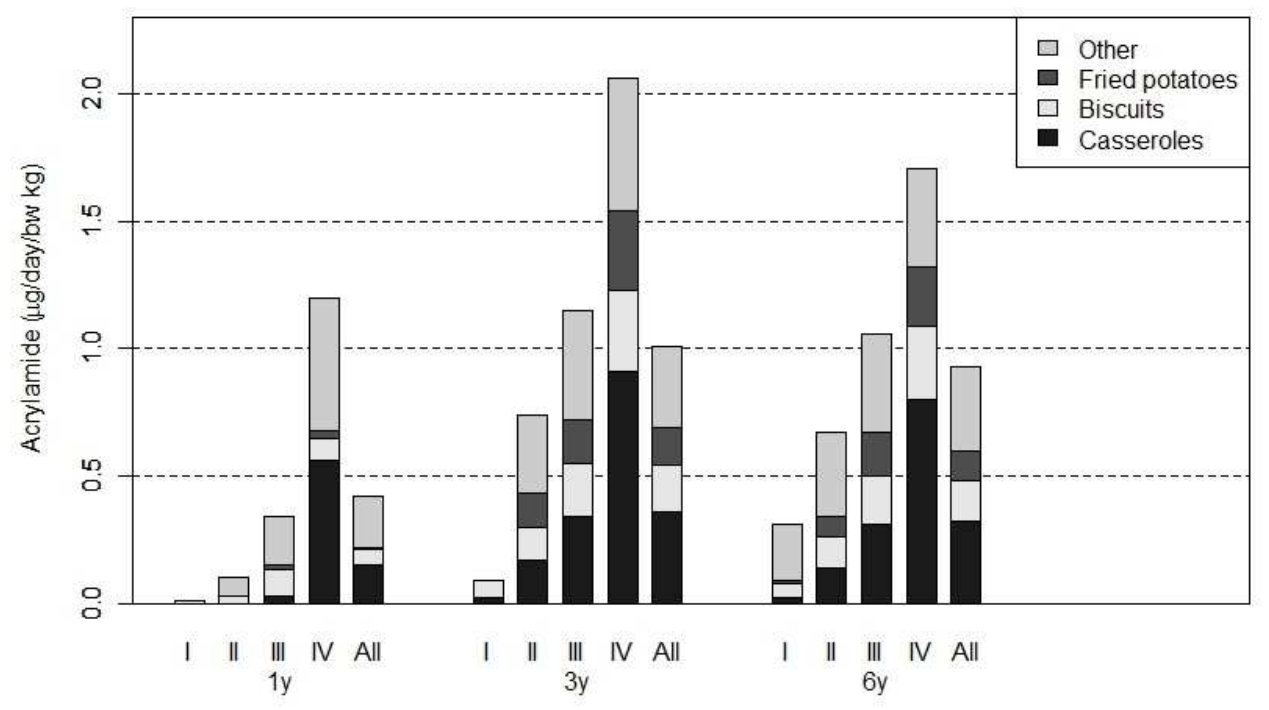

Dietary acrylamide exposure among children by major source, by age group, and by intake quartile. $293 \times 194 \mathrm{~mm}(72 \times 72$ DPI $)$ 
Men 45-64 years

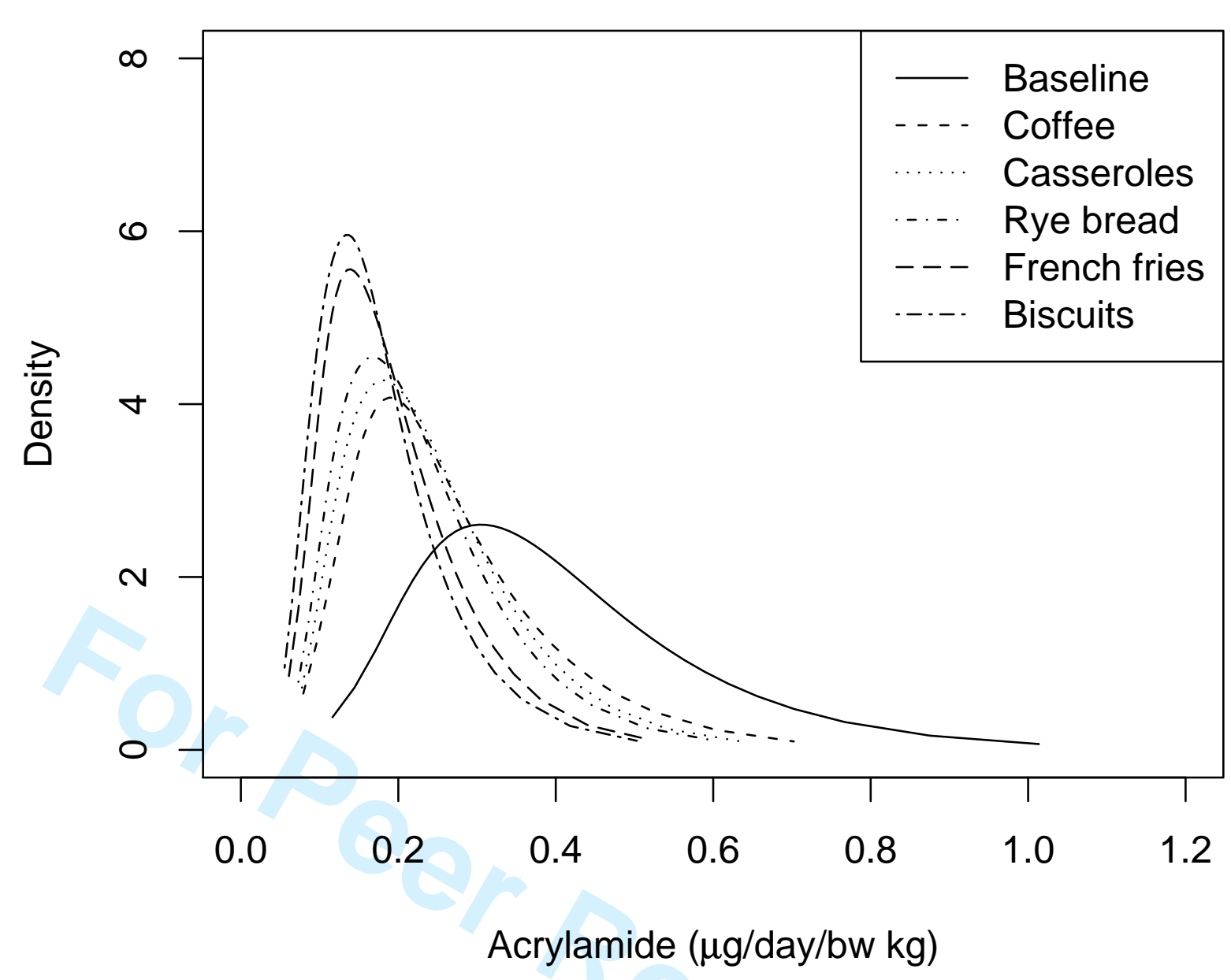

Women 45-64 years

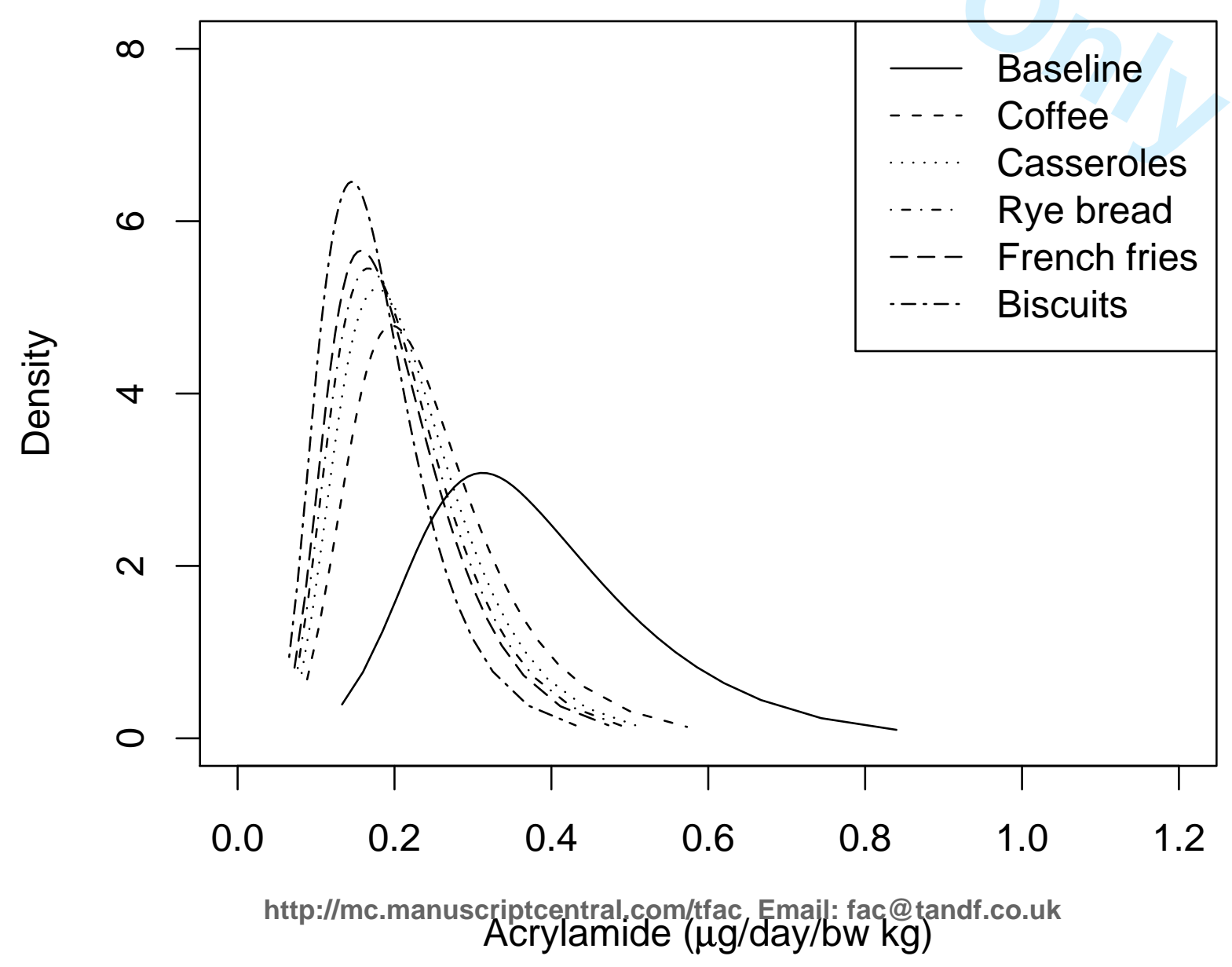

Men 65-74 years

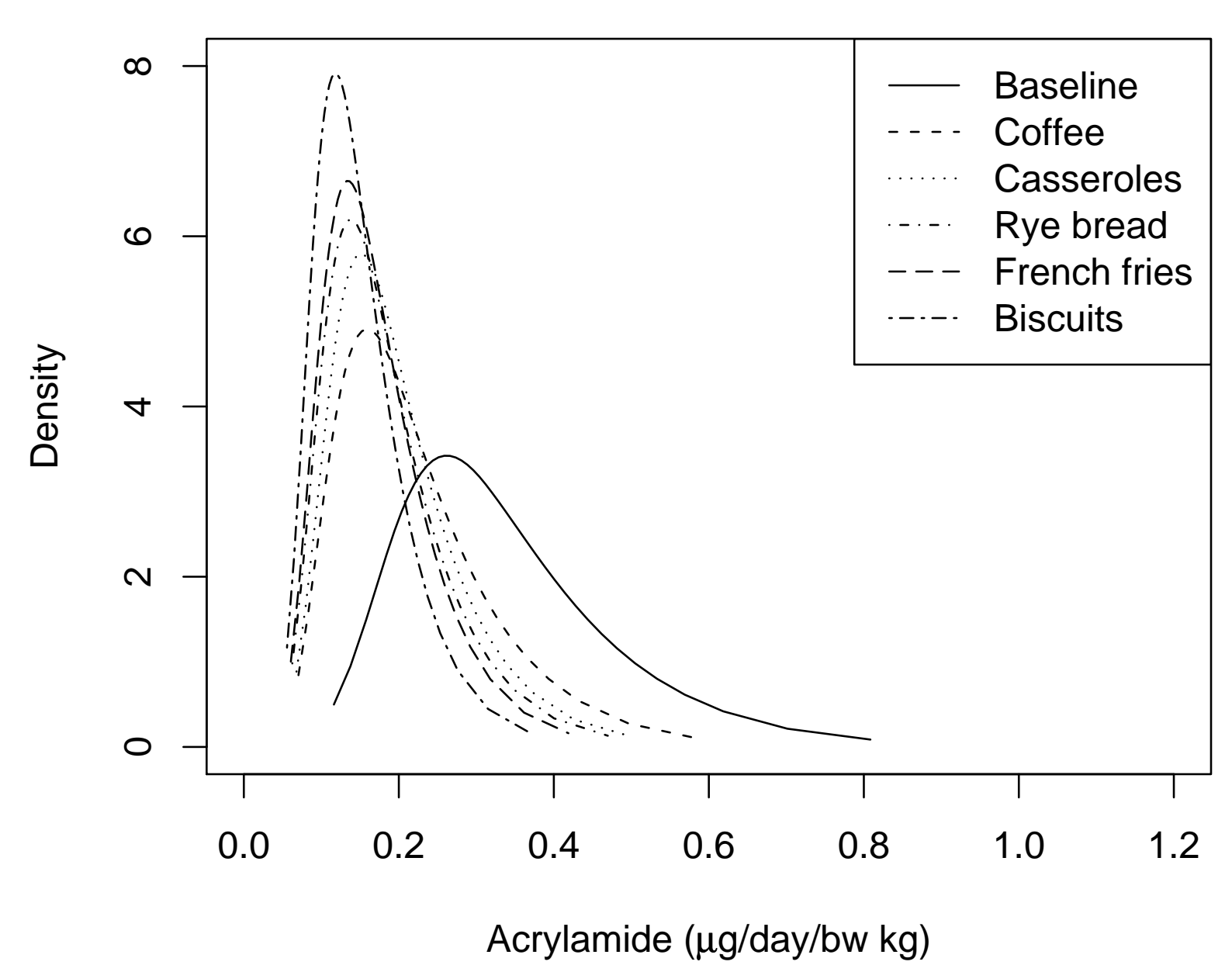

Women 65-74 years

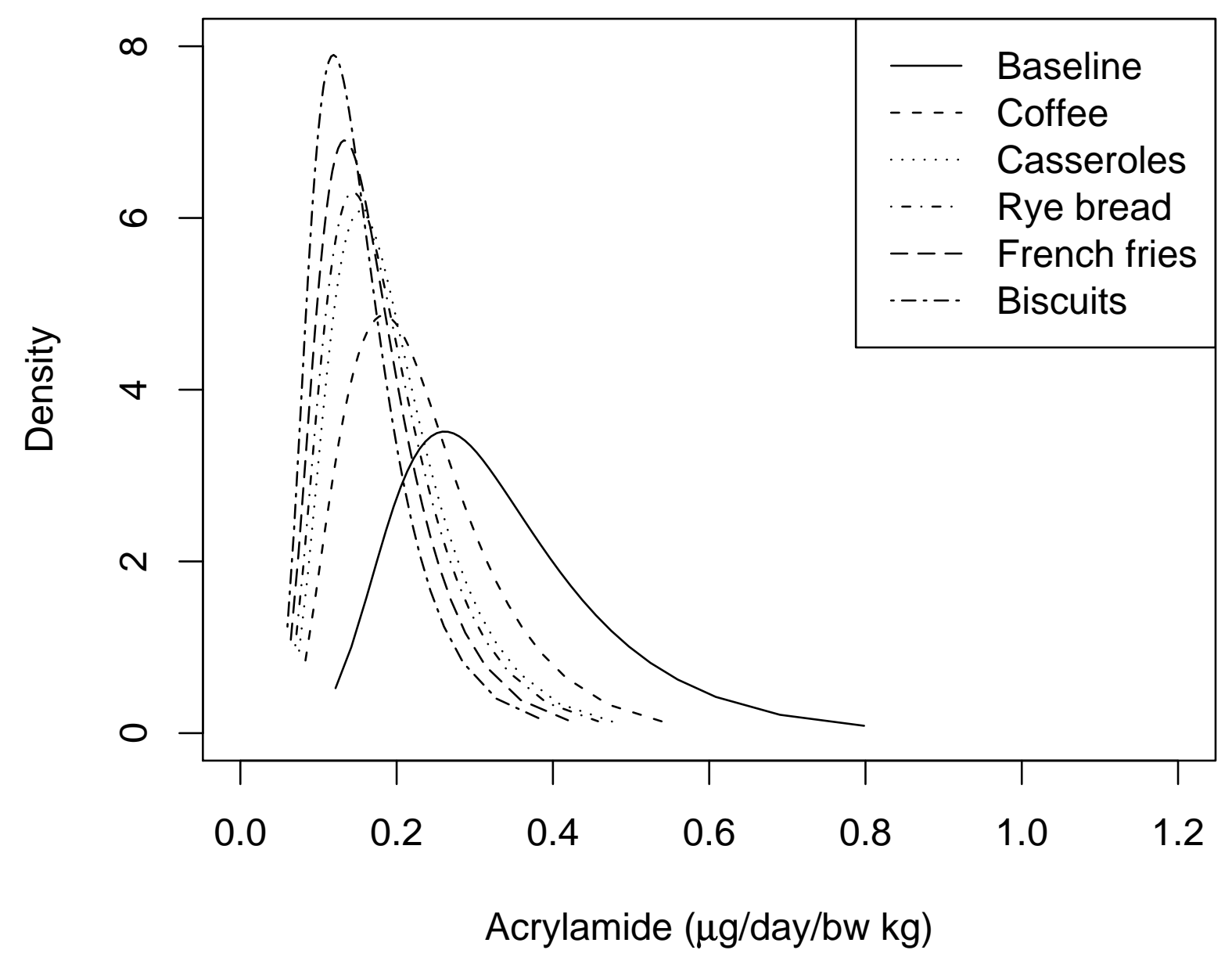




\section{Children 6 years}
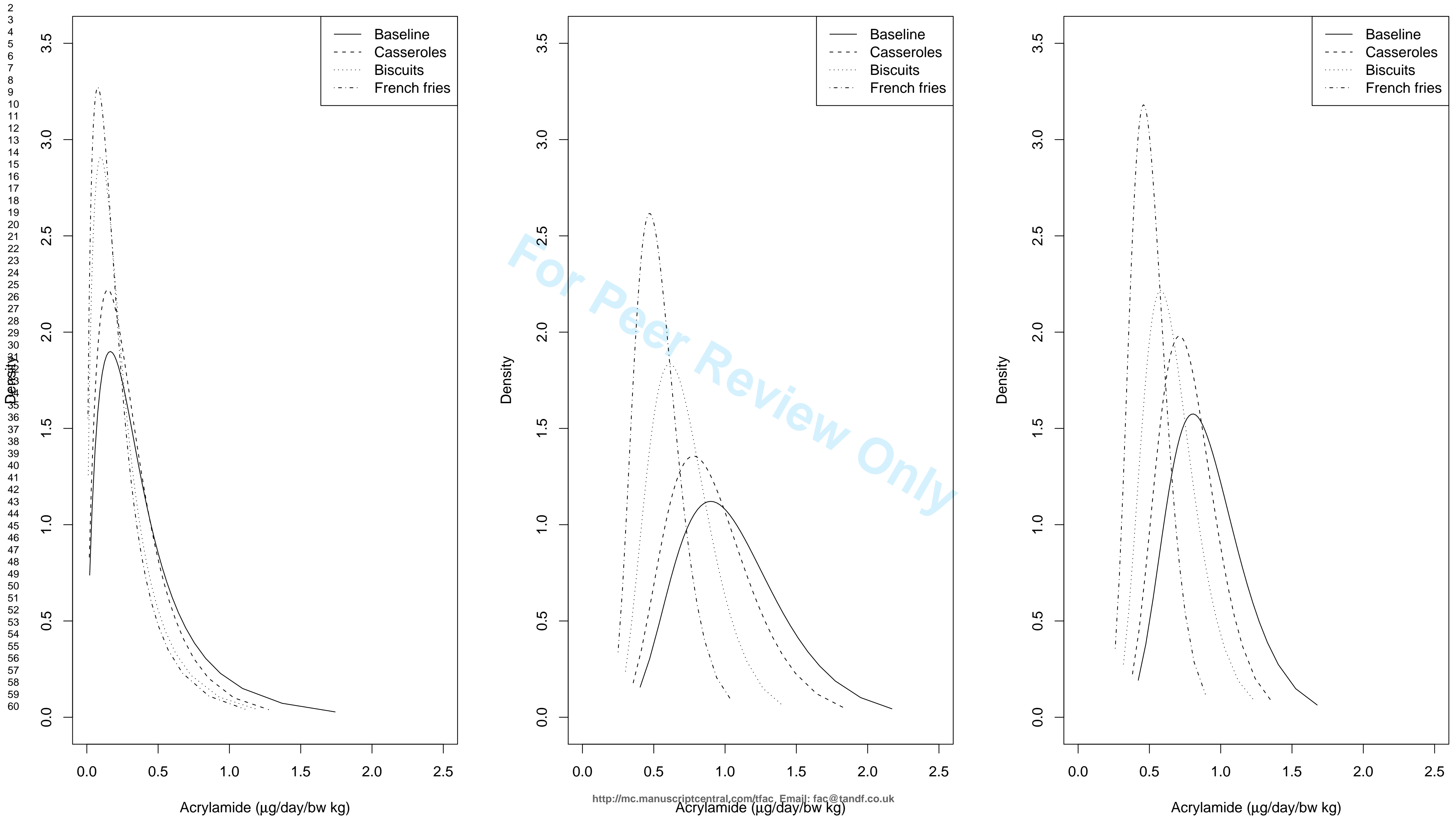